JALSAH: The Journal of al-Quran and as-Sunnah Studies

Faculty of Ushuludin IIQ An-Nur Yogyakarta

Vol. 1 No. 12021

https://jurnalannur.ac.id/index.php/jalsah

\title{
Mitologi dalam QS. Al-Kafirun Perspektif Semiotika Roland Barthes
}

\author{
Muhamad Jamaludin ${ }^{1}$, Nur Aini ${ }^{2}$, Ahmad Sihabul Millah ${ }^{3}$ \\ ${ }^{123}$ Institut Ilmu Al Qur'an An Nur Yogyakarta \\ mjamaludin09@gmail.com \\ DOI: https://doi.org/10.37252/jqs.v1i1.129
}

Abstract

The interpretation of Surah al-Käfirinn today is found to be a little disturbing for religious people, both among religions and between religious communities. Especially after the largest Islamic organization in Indonesia, namely Nabdatul 'Ulama which issued baḥsul masäil results about non-Muslims who are not infidels. Netizens are busy blaspheming and identifying non-Muslims as not even infidels to the point of stating that the meaning of the letter al-Käfirun today is no longer relevant. To answer this question, the author compiles Roland Barthes' theory of semiotics into this letter of al-Käfirin. The author interprets this letter of al-Käfirin using two levels of semiotics. The first level of semiotics analyzes linguistics or language. Meanwbile, the second level semiotics analyzes the connotative meaning in the text by revealing the mythical characteristics of the verse as stated in Roland Barthes' semiotic theory.

Keywords: Semiotic, Roland Barthes, Mitology Quran

\begin{abstract}
Abstrak
Penafsiran surat al-Käfirün dewasa ini dijumpai sedikit meresahkan umat beragama, baik sesama agama maupun antar umat beragama. Terlebih setelah organisasi Islam terbesar di Indonesia, yaitu Nahdatul 'Ulama yang mengeluarkan hasil bahisul masäil tentang non-muslim bukan kafir. Para netizen ramai-ramai menghujat dan mengidentikan non-muslim bukanlah kafir pun sampai menyatakan bahwa maksud dari surat al-Käfirün dewasa ini sudah tidak relavan lagi. Untuk menjawab persoalan tersebut, penulis mengompilakasikan teori semiotika Roland Barthes ke dalam surat al-Käfirün ini. Penulis menfasirkan surat al-Käfirün ini dengan menggunakan dua tingkatan semiotik. Semiotik tingkat pertama menganalisis linguistik atau bahasa. Sedangkan semiotika tingkat kedua menganalisis makna konotasi dalam teks dengan mengungkap ciri mitos pada ayat tersebut sebagaimana yang disebutkan dalam teori semiotika Roland Barthes.
\end{abstract}

\section{Kata Kunci: Alquran, al-Kāfirūn, Roland Barthes, Semiotika}

\section{Pengantar}

Justifikasi kafir yang dikeluarkan oleh sesama umat beragama atau terhadap antar umat beragama dalam kehidupan saat ini selalu menodong pada satu paham sarkasme propaganda yang berakibat meregangnya semangat toleransi di dalamnya. Salah satu surat dalam al-Qur'an yang mengakomodir konsep kafir adalah QS. al-Käfirün, sehingga sangat perlu adanya upaya penafsiran kembali surat al-Käfirün untuk menutup celah terhadap keregangan toleransi dalam beragama. Dalam surat al-Käfirün, Allah swt sangat jelas menyebutkan term kafir kepada makhluknya. Kendati demikian, penyimpangan keyakinan dalam menafsirkan kafir pada surat al-Käfirün dewasa ini dianggap sudah tidak relavan lagi. 
JALSAH: The Journal of al-Quran and as-Sunnah Studies

Faculty of Ushuludin IIQ An-Nur Yogyakarta

Vol. 1 No. 12021

https://jurnalannur.ac.id/index.php/jalsah

Sebagai contoh pada konteks ke Indonesiaan saat ini, penafsiran kafir mengalami perubahan makna. Hal ini dapat dilihat pada sebuah kasus tentang hujatan netizen terhadap salah satu organisasi Islam terbesar di Indonesia, Nabdatul 'Ulama, yang mengeluarkan hasil bạ̣sul masäil tentang non-muslim bukan kafir (https://www.nu.or.id/post/read/103224/tentang-non-muslim-bukan-kafir). Para warganet mengidentikkan non-muslim bukan kafir dengan menghujat dan mengatakan bahwa surat al-Käfirūn ini sudah tidak relavan lagi.

Penyimpangan penafsiran kafir yang dimaksudkan oleh netizen di atas merupakan bentuk tudingan penafsiran surat al-Käfirün telah membabibuta terhadap keyakinan umat Islam dalam kerukunan bernegara yang hidup berdampingan dengan agama-agama lainnya. Oleh karena itu, berbagai paradigma, prinsip, sistem dan dasar-dasar keyakinan tidak mustahil saling menjatuhkan justifikasi plurasime yang kebablasan. Oleh karena itu, dalam memaknai penafsiran kafir adalah wilayah yang sangat ekstra hati-hati dalam mengaplikasikannya dan mengimplementasinya.

Fakta sosial yang disebutkan di atas menunjukkan bahwa bahwa dewasa ini penafsiran surat al-Käfirim yang telah diuraikan beberapa mufasir sebelumnya masih menimbulkan persoalan yang belum tuntas bahkan menganggap keberadaan surat tersebut tidak relavan lagi. Oleh sebab itu, perlu adanya terobosan baru dalam menafsirkan kembali surat al-Käfirün guna menjawab persoalan di atas. Penafsiran tidak hanya dilakukan dalam tingkatan linguistik atau bahasa, tetapi dilakuan lebih mendalam dengan pembacaan pesan di balik makna literalnya dengan memanfaatkan teori semiotika Roland Barthes. Teori yang ditawarkan oleh Barthes mengusung sistem pemaknaan yang bertingkat, yaitu pemaknaan yang menjadikan linguistik sebagai titik tolak untuk memahami berbagai hal yang ikut menembus masuk ke dalam ayat tersebut. Selain itu, perlu adanya mengungkapan konteks sosiologi, sejarah, atau ideologi, sehingga dihasilkan pemaknaan yang komprehensif.

Cara kerja analisa semiotika Roland Barthes dalam menafsirkan surat al-Käfirūn bertolak dari struktur gramatikal kebahasaan sebagai semiotika tahap awal untuk menggali makna lebih dalam (baca: makna konotasi). Ia juga menggali makna lebih dalam lagi sebagai semiotika tahap keduanya hingga menemukan makna konotasi dari suatu teks. Selain itu, melalui semiotika Roland Barthes, penafsiran surat al-Käfirün dapat masuk lebih dalam lagi untuk menemukan konsep mitos (baca: mangusung makna konotasi dalam teks). Mitos yang ditawarkan Barthes mengungkapkan makna terdalam dalam sebuah tanda yang berangkat dari pemikiran Ferdinand de Saussure tentang konsep penanda (signifer) dan petanda (signifed) yang kemudian menghasilkan tanda itu sendiri (sign) (Barthes, 2017:19).

\section{Pembahasan}

\subsection{Sekilas Mengenai Semiotika}


JALSAH: The Journal of al-Quran and as-Sunnah Studies

Faculty of Ushuludin IIQ An-Nur Yogyakarta

Vol. 1 No. 12021

https://jurnalannur.ac.id/index.php/jalsah

Semiotika adalah sebuah ilmu yang dirintis oleh seorang tokoh filsuf yaitu Plato (s. 428-348 SM) yang memeriksa asal-muasal bahasa dalam cratylus. Aristoteles juga mencermati kata benda dalam bukunya poetics dan on interpretation. Kata semiotika berasal dari bahasa Yunani seme seperti dalam semiotikos, yang berarti penafsiran tanda. Sebagai suatu disiplin ilmu, semiotika berarti ilmu yang menganalisis tentang tanda atau studi tentang bagaimana sistem penandaan itu berfungsi (Cobley dan Litza Janz, 2020:4). Konsep dasar tentang tanda dalam dunia semiotika berpijak pada Ferdinand de Saussure yaitu sebagai pencetus strukturalisme, yang memperkenalkan konsep semiologi menjadi empat komponen. Adapun satu di antaranya yang menjadi komponen dasar semiotika adalah penanda (signifer), dan petanda (signifed).

\subsection{Konsep Dasar Semiotika Roland Barthes}

Berbicara tentang konsep semiotika Roland Barthes tidak akan terlepas dari pengaruh semiotika Ferdinand de Saussure. Saussure merupakan seorang tokoh yang mendiskusikan konsep dasar linguistik yaitu dikotomi speach dan language (Millah, 2017:60). Pernyataan ini yang nantinya diadopsi oleh Barthes untuk menentukan makna denotasi terhadap sebuah tanda untuk mengkaji lebih dalam lagi makna konotasi terhadap tanda itu sendiri.

Pada tahun 1956, Roland Barthes membaca sebuah karya Ferdinand de Saussure: Cours de linguistiqu generale kemudian melihat beberapa kemungkinan diterapkannya semiotik ke bidang-bidang lain. Ia mempunyai pandangan yang bertolak belakang dengan Saussure mengenai kedudukan linguistik sebagai bagian dari semiotik. Saussure justru berpandangan sebaliknya di mana semiotika bagian dari lingusitik karena tandatanda dalam bidang lain tersebut dapat dipandang sebagai bahasa yang mengungkapkan gagasan atau memiliki makna. Hal ini merupakan unsur yang terbentuk dari penandapetanda, dan terdapat di dalam sebuah struktur (Lustyantie, 2016:3).

Barthes dalam teorinya berupaya memisahkan semiologi dari linguistik. Meskipun, Ia membangun prinsip klarifikasi terhadap elemen-elemen semiologi yang dipinjamnya dari Ferdinan de Saussure, kemudian Ia mengelompokkannya ke dalam empat konsep utama secara dikotomis. Empat konsep utama itu adalah Langue dan parole, penanda dan petanda, sintagma dan sistem, Denotasi dan Konotasi. Dari keempat konsep ini lah semiotika Roland Barthes terbentuk.

\subsubsection{Langue dan Parole}

Langue merupakan suatu intitusi sosial dan sekaligus suatu sistem nilai (valeurvaleur). Sebagai institusi sosial dengan begitu langue merupakan hasil karya bersama invidual, karena individu tidak akan bisa menciptakan dan memodifikasikanya secara personal. Ia merupakan konvensi sosial yang harus ditaati seluruhnya jika ingin 
JALSAH: The Journal of al-Quran and as-Sunnah Studies

Faculty of Ushuludin IIQ An-Nur Yogyakarta

Vol. 1 No. 12021

https://jurnalannur.ac.id/index.php/jalsah

berkomunikasi (Barthes, 2017:22). Sebagai sistem nilai, langue terdiri dari elemenelemen yang masing-masing senilai dengan suatu terma dari sebuah fungsi yang lebih luas, di mana secara diferensial nilai-nilai lain yang korelatif memang ada (Barthes, 2007:17).

Parole merupakan tindakan individual kegiatan seleksi dan aktualisasi. Parole merupakan kombinasi-kombinasi yang digunakan subjek agar bisa mengunakan kode langue untuk mengungkapkan pemikiran peribadinya (Barthes, 2007:17).

\subsubsection{Petanda dan Penanda}

Petanda dan penanda dalam pemikiran Saussure merupakan komponen tanda. Barthes juga meminjam istilah ini dalam mengembangkan semiologinya. Petanda adalah sesuatu yang ditandai (signified) merupakan representasi mental dari sebuah benda. Petanda dan penanda merupakan sebuah kesatuan atau yang disebut Saussure adalah sebuah konsep. Petanda secara definisi merupakan sesuatu maksud atau yang dituju seseorang yang mengunakan tanda tertentu. Sedangkan petanda dan penanda berfungsi sama-sama sebagai salah satu dari dua noun atau tanda, hanya saja terlihat perbadaan di antara keduanya. Petanda adalah suatu hubungan atau mediator, adapun penanda membutuhkan materi. Kedua kegiatan ini adalah tindakan mengikat dan mengasilkan sebuah tanda (Faizah, 2015:38).

\subsubsection{Sintagma dan sistem}

Paradigmatik dan sistematik saling berkaitan dan memiliki hubungan. Hubungan keduanya adalah menghadirkan antara tanda yang terhubung secara berurutan dalam satu linearitas tindakan Bahasa (Faizah, 2015:39). Sintagmatik memiliki kaidah atau beberapa hukum yang secara tidak sadar selalu diikuti oleh penutur bahasa. Sebagai contoh pada kata 'baca'. Kata ini tersusun atas beberapa huruf abjad 'b' 'a' 'c' 'a'. Bagian dari susunan kata ini merupakan sintagmatik sedangkan gabungan dari huruf ini sehingga memiliki makna dibalik kata 'baca' merupakan sebuah sistem. d. Denotasi dan Konotasi

Denotasi adalah signifikasi tingkatan pertama pada semiotika Roland Barthes yang menelisik di ruang lingkup kebahasaaan. Dalam hal ini, penanda berhubungan dengan petanda sehingga membentuk sebuah tanda. Signifikasi tingkatan pertama ini merupakan sebuah pemikiran Saussure yang kemudian dikembangkan oleh Roland Barthes. Tanda ini berfungsi menandakan atau yang dihasilkan oleh aspek material dan aspek mental. Dengan begitu tanda (sign) memiliki tiga wajah yaitu tanda itu sendiri (sign), penanda (signifed), dan petanda (signifer) (Millah, 2017:129).

Konotasi merupakan sebuah sistem, terdiri dari penanda-penanda, petandapetanda, dan proses yang menyatukan sistem pertama ke dalam sistem yang ke dua (signifikasi) (Barthes, 2017:129). Melalui makna konotasi ini, Barthes mencoba https://jurnalannur.ac.id/index.php/jalsah 
JALSAH: The Journal of al-Quran and as-Sunnah Studies

Faculty of Ushuludin IIQ An-Nur Yogyakarta

Vol. 1 No. 12021

https://jurnalannur.ac.id/index.php/jalsah

menyingkirkan dan menolak ketertutupan makna sebagai reaksi melawan leksikal denotasi yang bersifat opresif (baca: sewenang-wenang) ini. Dengan demikian, semiologi yang diusung Roland Barthes menjelaskan tingkatan-tingakatan sistem bahasa yang terbagi menjadi dua tingkatan. Bahasa pada tingkatan pertama adalah bahasa sebagai objek dan pada tingkatan kedua disebut sebagai metabahasa. Jika keduanya telah dilakukan, maka akan timbul tanda kedua yang dikenal sebagai mitos dalam masyarakat. Dengan diterapkannya dua tahapan semiologis dalam pemahaman ayat-ayat Alquran, maka ayatayat ini tidak mungkun kehilangan makna literalnya, melainkan juga didapat pesan yang "sebenarnya" ingin disampaikan berdasarkan pada konteks yang mengelilinginya. Sebagaimana dipahami pada sekema berikut ini:

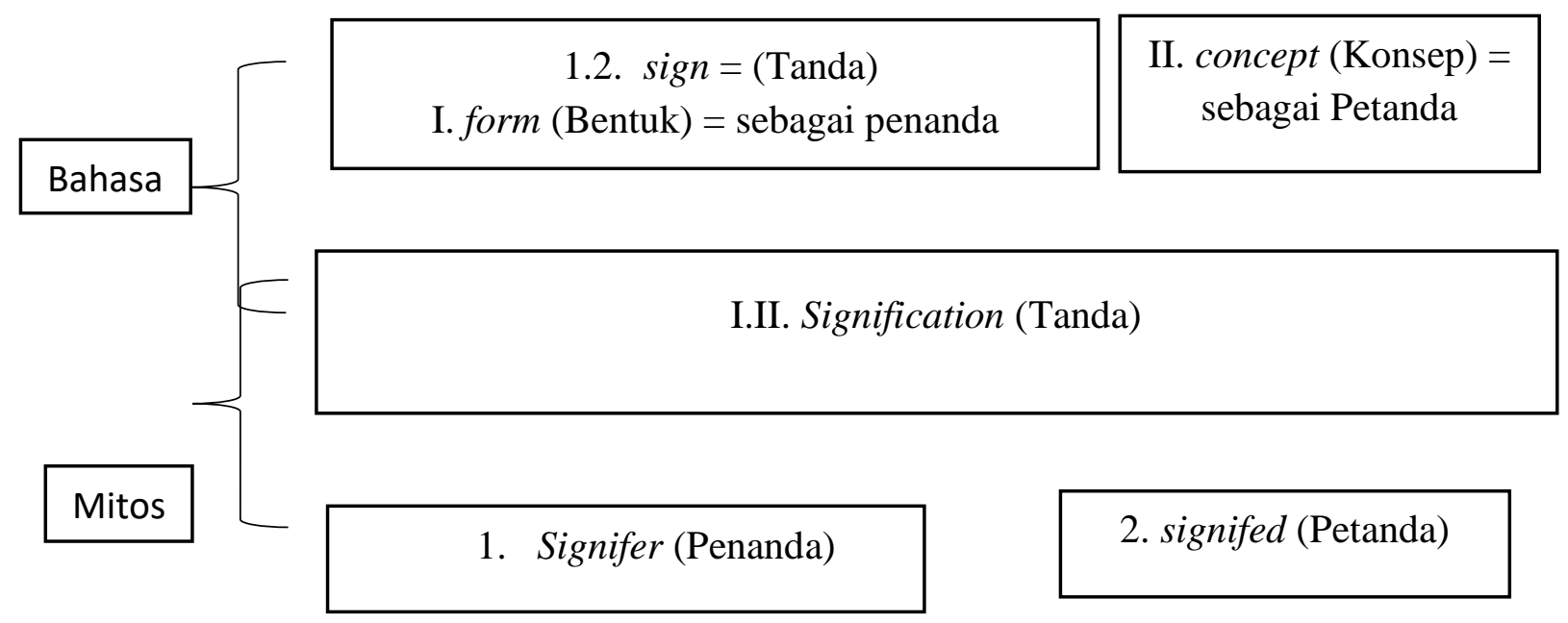

Dari skema di atas dapat dilihat kalau dalam mitos terdapat dua sistem semiologis, di mana salah satu sistem tersebut disusun berdasarkan keterpautannya dengan yang lain (Barthes, 2018:162). Selain itu, dari skema di atas kita melihat bahwa sistem mitos sebagai sistem semiotik tingkat kedua dapat kita jabarkan secara lebih rinci untuk kepentingan analisis. Sebagai sistem mitos, dia berdiri dari signification, form, dan concept. Karena sistem mitos adalah juga sistem semiotic (St Sunardi, 2013: 95-96).

Dalam mitologi Roland Barthes ini objek kajian pertama diposisikan sebagai tanda. objek yang sudah diposisikan sebagai tanda ini akan dikaji, dimaknai, dan dibuat berbicara tentang dirinya sendiri. Dari skema di atas dapat dilihat bahwa ada dua sistem semiologi, yaitu bahasa dan mitos. Pada sistem bahasa ini Barthes menggunakan istilah bahasa-objek, ini berarti mitos dibentuk oleh sistemnya sendiri. Selai mitos juga disebut sebagai 
JALSAH: The Journal of al-Quran and as-Sunnah Studies

Faculty of Ushuludin IIQ An-Nur Yogyakarta

Vol. 1 No. 12021

https://jurnalannur.ac.id/index.php/jalsah

metabahasa, karena ia merupkan menggalian makna kedua, tempat bahasa pertama dibicarakan (Barthes, 2018:163).

Mitologi Barthes juga menjelaskan pada tingkatan mitos disebutkan dengan sebutan bentuk. Adapun petanda, dapat dipastikan akan tetap disebutkan dengan konsep. Korelasi antara keduanya dalam sistem linguistik disebut tanda; namun di tingkat kedua, kita tidak mungkin menggunakan kata ini lagi tanpa ambiguitas, sebab dalam mitos penanda telah dibentuk oleh beberapa tanda bahasa. Istilah dalam sistem mitos disebut penandaan (signification)(Barthes, 2018:164). Untuk mendapatkan makna pada mitos tidak semua prinsip tingkat pertama berlaku pada semiotika tingkat kedua. Mitos memang dibangun dari semiotika tingkat pertama, akan tetapi tidak semua prinsip tingkat pertama berlaku pada semiotika tingkat kedua karena keberadaannya mendistorsi atau mendeformasi makna sebenarnya yang berada pada semiotika tingkat pertama. Dari situ kemudian muncul makna baru. Kelahiran makna baru harus ditopang dengan keberanaan kode budaya atau sejarah yang melingkupinya (Millah, 2017:190).

Millah (2017:191) menjelaskan juga bahwa mitos atau yang disebut sebagai type of speech yang diusung oleh Barthes setidaknya memiliki 4 ciri, yaitu: (1) Distortif. Sesuatu bisa dikatagorikan menjadi mitos ketika keberadaanya mendistorsi dirinya sendiri dengan adanya dua makna sekaligus, yakni makna denotatif dan konotatif; (2) Intensional. Mitos tercipta bukan asal jadi, melainkan kaya dengan tujuan (intensional); (3) Statement of fact. Keberadaan mitos menjadi bukti bahwa konsep itu faktual. Ia menjadi konsep yang tidak bisa diganggu gugat. Ia mejadi fakta aktual; (4) Motivasional. Adalah salah besar jika ada orang mengatakan mitos lahir tanpa motivasi. Mitos selalu dikerumuni motivasi. Bahkan, motivasilah yang selalu membayang-bayangi hidupnya.

\subsection{Semiotika dalam Surat al-Kāfïrūn}

\subsubsection{Semiotika tingkat pertama}

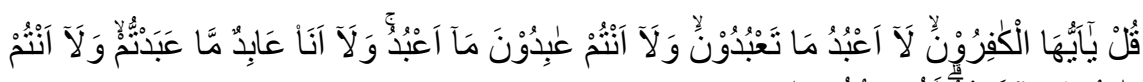

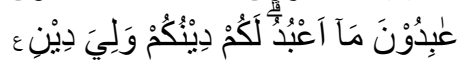

Artinya: Katakanlah (Muhammad), "Wahai orang-orang kafir!, aku tidak akan menyembah apa yang kamu sembah, dan kamu bukan penyembah apa yang aku sembah, dan aku tidak pernah menjadi penyembah apa yang kamu sembah, dan kamu tidak pernah (pula) menjadi penyembah apa yang aku sembah. Untukmu agamamu, dan untukku agamaku.” (Kemenag, 2002).

Penanda (signifier) pada ayat pertama surat ini adalah قل ياليها الكافرون. Sedangkan yang menjadi petandanya adalah Redaksi kata قل (ad-Dausy, 1993:600). Redaksi ini merupakan fíil amr dari fíil màḍ̂̀ قال /Katakanlah/ mengandung arti 
JALSAH: The Journal of al-Quran and as-Sunnah Studies

Faculty of Ushuludin IIQ An-Nur Yogyakarta

Vol. 1 No. 12021

https://jurnalannur.ac.id/index.php/jalsah

perintah Allah kepada Nabi Muhammad saw. Sedangkan redaksi يايها الكافرون / Hai orang-orang kafir/ adalah petanda untuk memanggil para pemangku kaum Quraish. Sementara redaksi الكافرون /orang-orang kafir/ merupakan sifat yang dimiliki oleh

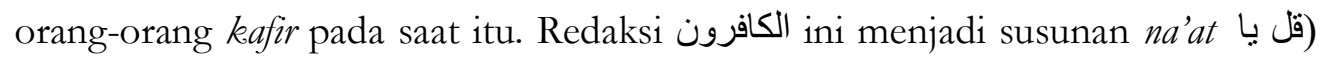

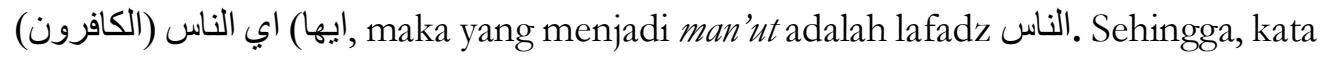
dapat dipahami sebagai sifat orang-orang yang menjadi lawan bicara Nabi Muhammad saw. Sehingga makna denotasi pada ayat pertama ini merupakan perintah Allah kepada Nabi Muhammad saw untuk memanggil orang-orang yang memiliki sifat kekafiran pada saat itu. Panggil ini merupakan penjelasan terhadap perbedaan keimanan antara Nabi dan orang-orang Qurasih pada saat itu.

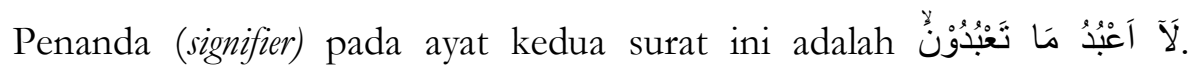
Penggunaan redaksi آَعْبُ penolakan Nabi terhadap ajakan menyembah Tuhan selain Allah SWT. Huruf $\gamma$ pada ayat kedua ini secara gramatikal kaidah nahwu termasuk harfu nafyin yang tetap/mabni atas sukun yang masuk pada fíil mudàri'. Huruf lā yang masuk sebelum fi'il mudāiri mengandung makna mustaqbal atau pekerjaan yang memiliki kurun waktu yang akan datang (Zamaksyari, 2009:1225). Hal ini menjadi petanda bahwa Nabi menolak terhadap ajakan menyembah Tuhan selain Allah swt. Sedangakan penggunaan redakai مَا تَعْبُدُْْونَ /Tidak menyembah apa yang kamu sembab/ merupakan cara penanaman keyakinan terhadap kebenaran yang disembah Nabi Muhammad dan pengikutnya (kaum muslim).

Huruf L adalah isim maushul musytaraq (Ghulayaini, 1993:131-136 ) yang kedudukannya menjadi maf'ul bib/obyek karena menempati i'rab nașab dari fi'il mud̄ari' لا أعبد. Sedang kata تعبدون tersebut menjadi șilah yang tidak mempunyai kedudukan. Adapun 'aidnya adalah huruf الهاء yang dibuang. Namun, jika ia ditampakan maka redaksi katanya menjadi “تعبدونه” (ad-Dausy, 1993:601). Melihat pada redaksi ayat ini, bahwa hal ini sebagai penanda dari sebuah penjelasan terhadap apa yang disembah oleh orang-orang kafir Quraish pada saat itu. Huruf ما yang masuk kedalam fi'il mudäri' ini menunjukkan makna الحال atau keterangan (Zamaksyari, 2009:1225). Artinya, kohesi ini merupakan penjelasan bahwa Tuhan yang disembah oleh orang-orang kafir Quraish tentu berbeda dengan Tuhan yang disembah oleh Rasulullah SAW dan kaum muslimin. Sehingga secara denotasi ayat ini mengandung makna bahwa Nabi mengingkari untuk menyembah tuhan orangorang kafir pada saat itu, karena terdapat perbedaan sifat Ketuhanan antara Nabi dan orang-orang kafir.

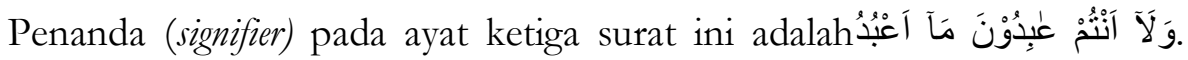

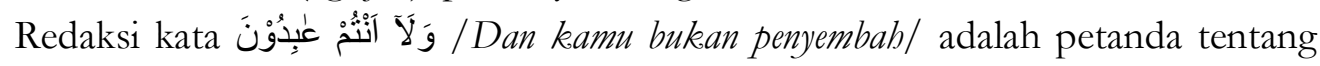


JALSAH: The Journal of al-Quran and as-Sunnah Studies

Faculty of Ushuludin IIQ An-Nur Yogyakarta

Vol. 1 No. 12021

https://jurnalannur.ac.id/index.php/jalsah

penggambaran bentuk penolakan dakwaan Nabi terhadap orang-orang kafir Quraish. Huruf الواو adalah huruf 'ațaf yang mutlaqul jam'i (al-Bajuri, 2012:50), yang mana ma'tüf-nya mengikuti kata lainnya, yaitu pada ayat sebelumnya yang terdapat

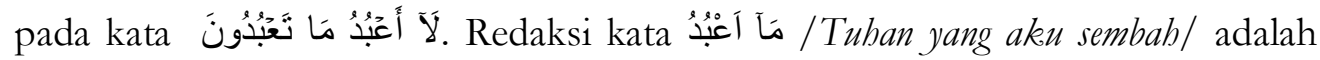
sebagai petanda untuk penjelasan tentang perbedaan sifat ketuhanan antara Tuhan orang-orang kafir yang mereka sembah dengan Tuhan yang disembah oleh Nabi Muhammad saw beserta kaumnya.

Huruf L pada redaksi kata ini adalah isim mauṣül/kata sambung yang jatuh setelah kata kerja “عابدون”. Kata عابدون adalah șilah-nya untuk menyempurnakan kata . dilihat dari segi kohesifitas, ini merupakan sebuah penanda tentang penjelasan Allah dengan menambahkan kembali pernyataanNya terhadap apa yang perintahkan kepada Nabi untuk disampaikan kepada orang-orang kafir, bahwa mereka tidak menyembah Tuhan yang telah didakwahkan Nabi selama ini. Hal ini dikarena bahwa sifat Tuhan yang didakwahkan Nabi jelas berbeda denga sifat Tuhan yang selama ini orang-orang kafir sembah, dan tidak mungkin kedua hal ini dipertemukan ke dalam bentuk yang sama-sama disepakati. Sehingga, makna denotasi ayat ini mengisyaratkan bentuk penolakan Nabi terhadap ajakan orang kafir, serta mengisyaratkan apa yang disembah orang kafir akan kemungkinan berbeda dari waktu-kewaktu.

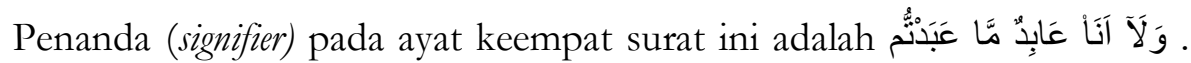

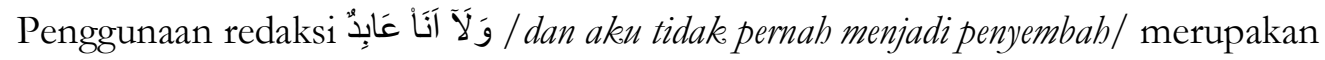
sebuah petanda untuk menggambarkan konsistensi Nabi dalam penyembahannya. عenggunaan kata عَابِد merupakan bentuk fä’il dari kata kerja a'budu, dan kata juga kedudukannya sebagai khobar dari kata انا. Melihat dari subyek kalimat ini, kata ini menunjuk kepada Rasulullah saw. Kohesi pada ayat sebelumnya memiliki perbedaan makna yang terdapat pada penyebutan kata kerja ibadahnya. Kohesi ini digunakan untuk menunjukkan penyembahan pada masa lampau, karena bersandar pada fíil mädi dan bersifat menerangkan pada masa lalu. Sedangkan, pada ayat empat kata ini disandarkan pada fi'il mudäri' yang menunjukkan masa yang akan datang dan masa saat ini. Hal ini merupakan petanda adanya sebuah isyarat bahwa yang disembah orang-orang kafir pada masa lalu ada kemungkinan berbeda dari yang disembah mereka pada saat ini, atau yang akan datang. Hal ini menjadi bukti pada saat penaklukan Mekah yang dilakukan Nabi beserta umat muslim, orang-orang kafir Quraish pada waktu berbondong-bondong masuk agama Islam. Sedangkan, penggunaan kata 'äbid yang terdapat pada ayat keempat ini, menyatakan sebuah konsistensi Nabi dalam beribadah, seperti yang ditunjukkan pada ayat ketiga dan kelima, dengan menggunakan bentuk redaksi yang sama, yaitu fi'il mudạri', atau kata kerja masa kini, dan yang akan datang. 
JALSAH: The Journal of al-Quran and as-Sunnah Studies

Faculty of Ushuludin IIQ An-Nur Yogyakarta

Vol. 1 No. 12021

https://jurnalannur.ac.id/index.php/jalsah

Penggunaan redaksi “apa yang kamu sembah.” Merupakan penjabaran tentang perubahan penyembahan orang-orang kafir terhadap apa yang mereka sembah.

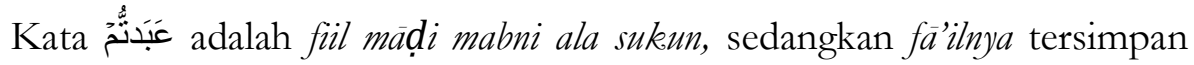
pada kata انتم. kohesi ini merupakan penggambaran tentang Tuhan yang disembah oleh orang-orang kafir pada saat masa lampau. Sedangkan, kata ini jatuh setelah kata $\mathrm{L}$ yang mengandung arti bahwa apa yang disembah oleh orang-orang kafir pada masa lampu merupakan berhala yang dianggap mereka sebagai Tuhan, sedangkan berhala tidak memiliki akal dan tidak memiliki daya upaya. Kohesi ini jika di perhatikan dengan ayat sebelumnya memiliki perbedaan kedudukan dari fi' $i l$ muḍäri' kemudian beralih menjadi fìil mädi i. Hal ini sebagai penanda bahwa Tuhan yang di sembah oleh orang-orang kafir dan cara penyembahan mereka terhadap Tuhan-tuhan mereka mengalami perubahan (tidak adanya konsistensi dalam ketauhidan mereka). Sehingga dengan demikian makna denotasi ayat keempat ini adalah pengambaran bentuk konsistensi nabi dalam beribadah dan menyembah Allah swt. Selain itu, ayat ini juga menggambarkan tentang tidak konsistennya orang-orang kafir dalam menyembah kepada Tuhan yang mereka yakini.

Ayat kelima surat pada al-Käfirūn merupakan bentuk pengulangan dari ayat ketiga. Sehingga hemat peneliti untuk mengkaji makna denotasi pada ayat kelima ini, sama seperti apa yang disebutkan pada ayat ketiga di atas. Hanya saja, pada ayat ini peneliti memaparkan beberapa pendapat ulama terkait hikmah di balik pengulangan ayat ini. Para pakar sastra dan bahasa berbeda pendapat tentang pengulangan yang terdapat dalam surat ini. Ada yang mengatakan bahwa pengulangan ayat pada surat ini sebagai bentuk penguatan, dan ada pula yang mengatakan bukan bentuk penguatan.

Menurut Ibnu 'atiyah berkaitan dengan pengulangan ayat ini, adalah jika ayat itu disandarkan untuk zaman sekarang dan selebihnya untuk zaman yang akan datang dengan menunggu ayat yang di dalamnya terdapat keterangan, dengan ayat "و لا أنا عابد ما عبدتم". hal ini bermaksud bahwa, seperti pada ucapan "selamanya kami tidak akan menyembah sesembahan kalian", kemudian muncul ayat "و "و لا انتم عابدون ما اعبد "sebagai redaksi yang kedua karena dianggap perlu kepada mereka orang-orang kafir. Sesungguhnya, redaksi ini menggambarkan bahwa orang-orang kafir tidak akan beriman selama-lamanya. Inilah yang disebut pengulangan makna yang terdapat pada surat ini, dan paling diunggul kefasihan tidak hanya pengulangan saja melainkan di dalamnya terdapat sesuatu yang disebutkan (ad-Dausy, 1993:602).

Menurut Ibnu Abbas, bahwa ayat ini menggambarkan tentang perkataan orang kafir Quraish "harta kami berikan kepada kalian tidaklah lantas anda paling 
JALSAH: The Journal of al-Quran and as-Sunnah Studies

Faculty of Ushuludin IIQ An-Nur Yogyakarta

Vol. 1 No. 12021

https://jurnalannur.ac.id/index.php/jalsah

kaya di Kota Makkah dan kami menikahi perempuan-perempuan semau kami dan kami berjalan mengikutimu maksudnya kami berjalan dibelakangmu dan kamu menahannya dari menghina Tuhan kami maka jika kamu tidak melakukan hal itu maka kami menawarkan kepadamu suatu praket yaitu kebaikan untuk kami dan untukmu, penyembahanmu terhadap Tuhan kami itu sebagai alat dan kemulyaan. Dan kami menyembah Tuhan Kalian selama satu tahun kemudian kalian menyembah Tuhan Kami, maka kami memberlakun tahun demi tahun". Maka turunlah ayat ini, adapun adanya pengulangan ayat " أعبد ما تعبدون” karena orangorang kafir mengulang ucapan berkali-kali (ad-Dausy, 1993:603).

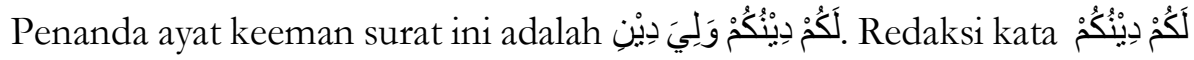
/ Untukmu agamamu merupakan petanda terhadap penggambaran sebuah pertanggung jawaban atas perbuatan orang-orang kafir Quraish. Kata لكم adalah Khobar yang wajib didahulukan (Bakar, 2018:157), sedangkan huruf $J$ harus diharakati fathah, karena betemu dengan isim deàmir, yaitu huruf merupakan keduduan sebagai mubtada yang diakhirkan. Namun, mubtadanya terbentuk dari nakirah dan khabar berupa dzaraf dan jar majrur (Bakar, 2018:157), sadangkan kata دين adalah isim mașdar dari دان Kata ini bentuk fi'il mad $\}$ i mu'tal ajwaf wawi berasal dari kata دَوَنَ alif, karena berharakat fathah yang bersambung dalam satu kalimat, maka makna katanya menjadi “دان" (Nazir, ttp:8). Kata ini mengandung arti “agama”, “balasan”, atau "kepatuhan" (Shihab, 2005:684). Sedangkan, kata sُ adalah ḍamìr muttașil (Busro, 2015:42) yang menunjukan orang yang diajak bicara yaitu sebagai pihak ketiga.

Redaksi kata دوَلِيَ دِيْن / untukkeulah, agamaku merupkan petanda tentang penggambaran adanya kebebasan memilih kepercayaan yang diyakini masingmasing orang. Huruf الواو adalah huruf 'ațaf pada kata sebelumnya, dan huruf adalah khobar muqadam (Bakar, 2018:157). Selain itu, huruf J juga mud̄äf kepada ya' mutakallim yaitu pada huruf الياء, maka huruf J diharakati dengan kasrah. Akhir huruf mudäf yang berhubungan dengan ya mutakalim dikasrabkan, hal ini berlaku manakala ia bukan isim maqsyur, manqus, mus|ana, dan bukan pula jama muغ̇akar salim. Dalam hal ini, disamakan dengan isim mufrad kedua jenis jama' taksir, jama' muanas salim dan mufrad mu'tal yang diberlakukan sama dengan mufrad sabih muqadam (Bakar, 2018:532). Adapun kata دين adalah menjadi mubtada muakhar. Kohesi kata ini merupakan penanda bahwa kata liya di atas berfungsi menggambarkan kekhususan (Shihab, 2005:684). Berdasarkan penggambaran ini, sangat tampak bahwa agama haruslah berdiri sendiri tidak perlu dicampur adukkan satu sama lainnya. hal ini merupakan bentuk pengakuan bahwa agama itu bersifat mutlak bagi pemeluknya. Dan juga dalam beragama tidak perlu 
JALSAH: The Journal of al-Quran and as-Sunnah Studies

Faculty of Ushuludin IIQ An-Nur Yogyakarta

Vol. 1 No. 12021

https://jurnalannur.ac.id/index.php/jalsah

mengajak untuk saling menyembah dalam perbedaan agama satu sama lainnya. selain itu ayat ini juga menegaskan bahwa dipersilahkannya menganut dan mempercayai agama manapun yang diyakininya. Sehingga, makna denotasi ayat ini merupakan penggambaran eksistensi secara timbal balik dalam prilaku beragama satu sama lainnya. Secara teks, terdapat makna tersurat bahwa "bagi kamu agamamu, dan bagiku agamaku" sehingga dengan argumentasi ini dapat dilihat bahwa semua pihak (pemeluk agama) di perkenankan memilih dan melaksanakan ibadah untuk menyembah Tuhan yang dianggapnya benar dan baik, tanpa memutlakkan pendapat.

\subsubsection{Semiotika tingkat kedua}

Berdasarkan hasil pengamatan, makna konotasi dalam al-Käfirūn ini hanya terdapat pada ayat pertama dan ayat kelima saja. Pada ayat pertama surat ini, yang menjadi bentu (form) adalah الكافرون يايها. Konsep (concept) pada ayat ini adalah mengandung pengertian "panggilan kepada umat muslim untuk memperhatikan kontradiksi terhadap claim keimanan di hatinya masing-masing. selain itu panggilan ini juga untuk "Muqasy-qasyah" membongkar makar terhadap tudingan kafir kepada sesama muslim". Hal ini didukung dengan kode kalimat "bai orangorang kafir" sebagai panggilan Allah kepada orang-orang kafir yang menjadi tanda pada semiotika tingkat pertama. Sedangkan signifikasi ayat ini menunjukkan bahwa bukan hanya mengandung arti "katakanlah (Muhammad) hai orang-orang kafir" yang merupakan panggilan Allah kepada orang-orang kafir untuk menggambarkan perbedaan keimanan antara orang-orang kafir dengan orang-orang muslim, sebagaiman yang telah disebutkan pada makna denotasi ayat yang peneliti sebutkan di atas. Akan tetapi ayat ini juga menunjukkan adanya panggilan Allah terhadap umat muslim untuk memperhatikan kontradiksi claim keimanan di antara sesama muslim. Selain itu, ayat ini juga merupakan panggilan Allah untuk membongkar 'makar' terhadap saling menuding kafir sesama umat muslim.

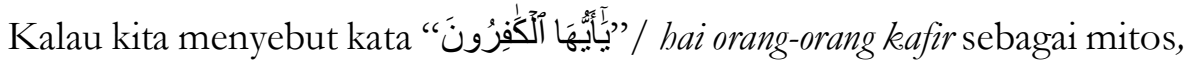
maka kata tersebut tak lebih hanya cara bicara Tuhan menyapa hamba-Nya. Segala sesuatu bisa menjadi mitos, tak terkecuali ayat ini, sejauh memiliki ciri-ciri yang mengarah type of speech (mitos). Ciri pertama adalah distortif. Ciri ini mengatakan bahwa sesuatu bisa dikatagorikan menjadi mitos ketika keberadaannya mendistorsi dirinya sendiri. Keberadaannya mengandung dua makna: denotatatif dan konotatif. Begitu juga pada ayat: “... hai orang-orang kafir”"ini. Kendati demikian, untuk makna denotatif redaksi ini telah peneliti sebutkan di atas. Maksud Allah menurunkan ayat ini bukan hanya panggilan terhadap orang-orang kafir, sebagaimana makna literalnya. Tetapi, Allah juga menurunkan ayat ini untuk memanggil dan menyapa orang-orang muslim atas kontradiksi claim keimanan 
JALSAH: The Journal of al-Quran and as-Sunnah Studies

Faculty of Ushuludin IIQ An-Nur Yogyakarta

Vol. 1 No. 12021

https://jurnalannur.ac.id/index.php/jalsah

yang ada di dalam hatinya. Hal ini sebagaimana yang dikatakan oleh Sayid Quthb (ttp:3991) dalam Tafsì Fi Zilali al-Quran yang mengatakan bahwa ayat ini adalah

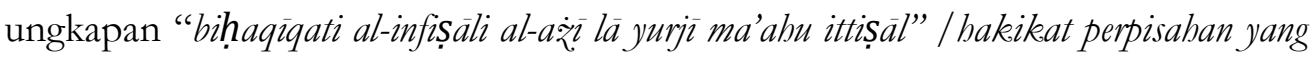
tidak mungkin bertemu/". Sayid Qutb mengarahkan maksud ayat ini dengan bentuk persifatan yang ada di dalam diri manusia yang tidak mungkin bisa disamakan sehingga bisa disimpulkan bahwa ayat tersebut mengarah pada pemanggilan Allah kepada orang-orang muslim atas kontradiksi claim keimanan yang ada di hatinya. Abuya Misbah Sadat dalam tafsirnya yang berjudul Selain itu, Abuya Misbah Sadat dalam kitab tafsirnya yang berjudul Ribät al-Qur'ān Surah al-käfirün dalam penelitian Zahrah (2019:52) menjelaskan bahwa ayat ini mengandung arti "Muqasyi qasiyah" yang berarti "membongkar makar" atas tudingan kafir terhadap sesama muslim.

Ciri yang kedua adalah intensional. Ayat pertama ini mememiliki tujuan (intensional) untuk menyapa, dan memanggil orang-orang muslim agar memperhatikan kontradiksi claim keimanan yang ada di hatinya masing-masing. selain itu Adanya panggilan ini juga bertujuan untuk "membongkar makar" terhadap tudingan kafir sesama muslim.

Ciri yang ketiga adalah statement of fact. Makna konotasi pada pertama ayat ini merupakan bukti bahwa konsep mitos yang terkandung di dalamnya adalah faktual (statement of fact). Bukti tersebut di antaranya yaitu: pertama, keimanan manusia membentuk pemahaman terhadap ideologi dan paradigma dalam beragama. Karena menusia menjadikan agamanya sebagai pondasi dasar untuk disakralkan seperti Tuhan, kitab suci, dan lainnya, yang dianggap sakral dalam agamanya. Adanya ideologi dan paradigma yang berbeda dalam beragama inilah yang menjadi dasar atas kontradiksi claim keimanan di hati sesama muslim. Sebagai contoh, sebagian golongan muslim memahami hadis tentang bid'ab sebagai "senjata" untuk menolak segala amaliah yang tidak ada di masa Rasulullah saw. Mereka serentak menyebut bidah adalah sesat yang harus ditinggalkan, agar tidak dikalim sebagai "ablun nar" (Iyubenu, 2017:51). Pandangan ini menjadi sekat atas sebagian golongan muslim lainnya ketika melalukan amaliah yang tidak ada di masa Rasulullah merupakan bentuk kesesatan.

Ciri yang terakhir adalah motivasional. Mitos selalu dikerumuni motivasi. Bahkan, motivasilah yang selalu membayang-bayangi hidupnya. Ayat ini juga memiliki bentuk motivasional sebagaimana ciri mitos yang peneliti sebukan di atas. Secara implisit kita bisa mengatakan bahwa ayat ini turun karena ingin memotivasi dan membimbing manusia agar tidak semena-mena terhadap keimanan di hati sesama muslim. Selain itu, ayat ini juga memotivasi pembaca agar 
JALSAH: The Journal of al-Quran and as-Sunnah Studies

Faculty of Ushuludin IIQ An-Nur Yogyakarta

Vol. 1 No. 12021

https://jurnalannur.ac.id/index.php/jalsah

tidak mudah menuding kafir sesama muslim selagi tidak menyinggung hal yang bersifat fundamental dalam ajaran Islam.

Tudingan atau klaim kafir terhadap hati manusia merupakan kuasa Allah swt yang tidak bisa diakses dengan mudah oleh manusia. Hal ini menjadi sangat rumit, pelik, berat, seperti mencari jarum di dalam tumpukan jerami, sehingga ia tergolong sesuatu masalah yang harus diwaspadai, penuh kehati-hatian, mesti berdasarkan ilmu yang mendalam, serta kebijaksanaan hati yang cemerlang.

Ayat ini memotivasi umat Islam agar lebih berhati-hati untuk memanggil atau mengklaim kafir dengan sembarang jika tidak menyinggung masalah fundamental dalam Islam. Imam al-Ghazali, misalnya, mengatakan bahwa seandainya seorang telah memiliki 99 jenis kemungkinan kafir, tetapi ada satu hal pada dirinya yang memungkinkannya untuk mukmin, maka tariklah ia ke dalam kemukmiman (Iyubenu, 2020:227).

Pada ayat keenam dalam surat ini yang menjadi bentuk (form) adalah كَكُمْ . دِينُكُم وَلِيَ دِينِ Konsep (concept) pada ayat keenam ini adalah “ tolarensi dan moderasi dalam beragama". Hal ini didukung dengan kode kalimat "Untukmu agamamu, dan untukkulah, agamaku". Signifikasi pada redaksi ini adalah "konsep tolarensi dan moderasi beragama". signifikasi ini menunjukkan bahwa ayat ini bukan hanya mengandung pengertian "Untukmu agamamu, dan untukeulah, agamaku" yang menunjukkan sikap toleransi terhadap agama-agama lain atau kebebasan manusia dalam memilih agamanya sebagaimana yang telah disebutkan dalam makna denotasi di atas. Akan tetapi ayat ini memiliki makna konotasi bahwa sikap toleransi itu juga harus dibangun terhadap perbedaan dalam memahami khazanah keislaman antar sesama umat muslim. Selain itu, ayat ini juga memiliki makna konotasi bahwa dalam beragama sesama muslim memiliki sikap moderat terhadap perbedaan pemahaman dalam khazanah keislaman.

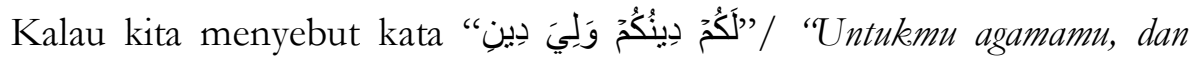
untukkulah, agamaku" sebagai mitos, maka kata tersebut tak lebih hanya cara bicara/wicara Tuhan menyapa hamba-Nya. Segala sesuatu bisa menjadi mitos, tak terkecuali ayat ini, sejauh memiliki ciri-ciri yang mengarah type of speech (mitos). Peneliti akan paparkan beberapa ciri mitos pada ayat ini, di antaranya sebagai berikut: Distortif. Ciri ini mengatakan bahwa sesuatu bisa dikatagorikan menjadi mitos ketika keberadaannya mendistorsi dirinya sendiri. Keberadaannya mengandung dua makna: denotasi dan kontekstualisasi. Kendati demikian, untuk mana denotasi pada kohesi ini telah peneliti sebutkan di atas. Sedangkan untuk makna kontekstualisasi ayat ini, Sadat dalam (Zahroh, 2019:25) mengatakan bahwa ayat ini mengandung makna toleransi/baräah (melepas diri) dan moderasi 
JALSAH: The Journal of al-Quran and as-Sunnah Studies

Faculty of Ushuludin IIQ An-Nur Yogyakarta

Vol. 1 No. 12021

https://jurnalannur.ac.id/index.php/jalsah

dalam beragama. Hal tersebut sebagaimana juga dikatakan oleh Sayid Qutb dalam tafsinya bahwa:

"ayat ini merupakan kesimpulan dari hakikat perpisahan yang tidak mungkin bertemu dan hakikat perbedaan yang tidak mungkin dicampuradukkan (konsep toleransi). Pemisahan ini adalah perlu untuk menjelaskan tanda-tanda perbedaan yang pokok yang mustahil dapat diadakan pertemuan di antara kedua-duanya, yaitu perbedaan dalam asas i'tiqad, dasar pemikiran, hakikat hidup dan tabiat dalam beragama (konsep moderasi)" (Quthb, ttp:3992).

Ungkapan Sayid Qutb di atas merupakan penafsiran terhadap makna

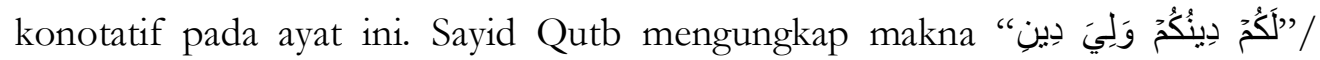
"Untukmu agamamu, dan untukkulah, agamaku" bukan hanya persoalan agama saja, tetapi Ia juga mengarahkan makna ini pada perbedaan dalam asas i'tiqad, dasar pemikiran, hakikat hidup dan tabiat, bukan hanya dalam kehidupan antar agama, tetapi juga dalam agama itu sendiri.

Ciri kedua adalah intensional. Makna mitos pada ayat ini memiliki tujuan untuk menyapa, menginformasikan, dan memberitahukan pembaca tentang adanya bentuk toleransi dan moderasi dalam beragama. Argumentasi ini di dasari atau diwakili dengan redaksi "Untukmu agamamu, dan untukkulah, agamaku” yang diperuntukkan dalam kehidupan beragama atau berkeyakinan dalam kepercayaan yang dianut manusia.

Ciri ketiga adalah statement of fact. Keberadaan mitos bukan hanya sebagai mediasi untuk menyapa pembaca terhadap pesan yang tersirat di dalamnya saja. Tetapi keberadaannya juga sebagai statement of fact. Dengan kata lain, ia bukan hanya sekedar ajakan, perintah, dan sapaan, melainkan menjadi bukti bahwa konsep tersbut bersifat faktual. Bukti faktual ini yang menyebutkan adanya nilai toleransi dan moderasi pada ayat ini, yaitu dapat digambarkan bahwa hubungan antara muslim dengan penganut agama lain tidak dilarang oleh syariat Islam, kecuali bekerja sama dalam soal aqidah, dan ibadah. Karena kedua persoalan ini merupakan hak internal umat Islam dan tidak bisa dicampuri pihak lain, tetapi aspek sosial kemasyarakatan dapat bersatu dalam kerja sama yang baik (Suryana, 2011:132). Pembatasan yang jelas dalam hal akidah atau kepercayaan ini merupakan upaya tidak terjebak pada sinkretisme. Dalam konteks ini, Hamka dalam tafsir surat alKäfirün menjelaskan bahwa akidah tidak dapat diperdamaikan, tauhid dan syirik tidak dapat dipertemukan. Kalau yang hak hendak disatukan dengan yang bathil, maka yang bathil menang. Aqidah taubid tidak mengenal sinkritisme artinya sesuai menyesuaikan, misal antara animisme dengan tauhid, penyembahan berhala dengan salat, menyembelih binatang untuk memuka berhala dengan membaca bismillah (Ghazali, 2016:30). 
JALSAH: The Journal of al-Quran and as-Sunnah Studies

Faculty of Ushuludin IIQ An-Nur Yogyakarta

Vol. 1 No. 12021

https://jurnalannur.ac.id/index.php/jalsah

Dengan demikian toleransi memiliki batasan-batasan terutama berhubungan dengan masalah akidah dan tauhid. Ajaran Islam dengan tegas juga melarang para pemeluknya untuk berprikalu seperti para penganut agama lainnya. Namun, pada saat yang sama Islam pun menyerukan untuk menghormati dan melihat orang yang berbeda agama secara pribadi yang utuh dengan semua hak dan kewajiban yang mesti dihargai. Islam melarang pemelunya untuk mencaci maki kepercayaan orang yang dianut agama lain, yang bisa mencederai kehidupan bersama dalam sebuah masyarakat.

Islam tidak melarang umatnya berhubungan dan berinteraksi dengan agama lain sejauh tidak menyangkut perkara keimanan dan akidah. Dalam lingkup ini saja Islam memperbolehkan, apalagi hanya perbedaan pendapat dalam memahami khazanah keislaman seperti perbedaan ijtihad, mahdzab, dan organisasi. Maka dari itu, ayat ini menjadi bukti bahwa hingga saat ini banyak perbedaan ideologi dan paradigma dalam memahami khazanah Islam di antara para pemeluknya.

Ciri keempat adalah motivasional. Mitos lahir selalu dirundungi motivasi. Bahkan motivasilah yang menjadi bagian dari mitos itu. secara implisit kohesi ini mengatakan bahwa ayat ini turun kerana ingin memotivasi pembaca agar bersikap toleransi, dan moderasi dalam beragama. ayat keenam ini merupakan bentuk pengakuan terhadap semua bangsa, budaya dan agama memiliki mitos masingmasing. mitos mengkolektif suatu budaya masyarakat akan menyampaikan pesan moral tertentu (Zajuli, 2014:315). Dengan demikian, adanya pengakuan terhadap perbedaan sebagaimana yang disebutkan ini, makna mitos ini menggerakan pembaca agar lebih menumbuhkan sikap toleransi, dan moderasi dalam beragama.

\section{Kesimpulan}

Setelah menganalisis segala aspek pembahasan tentang penafsiran surat al-Käfirün dengan menggunakan teori semiotika Roland Barthes, maka dapat disimpulkan bahwa:

Pertama, analisis pada semiotika tingkat pertama didapatkan makna denotasi di dalam surat ini meliputi: (1) Adanya perintah Allah kepada Nabi Muhammad saw untuk berdialog kepada orang kafir; (2) Adanya tindakan tegas untuk waktu yang akan datang Nabi tidak akan menyembah apa yang orang-orang kafir sembah, serta perbedaan cara peribadahan orang kafir dengan Nabi; (3). Mengisyaratkan apa yang disembah orang kafir akan kemungkinan berbeda dari waktu kewaktu; (4) Manusia dibebaskan untuk memilih agama atau kepercayaan yang dianutnya.

Kedua, analisis pada semiotika tingkat kedua didapatkan makna konotasi di dalam surat

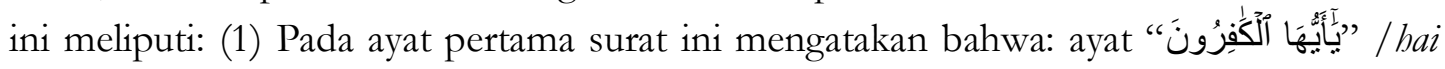
orang-orang kafir/ sebagai mitos tentang adanya panggilan Allah kepada orang-orang 
JALSAH: The Journal of al-Quran and as-Sunnah Studies

Faculty of Ushuludin IIQ An-Nur Yogyakarta

Vol. 1 No. 12021

https://jurnalannur.ac.id/index.php/jalsah

muslim untuk memeperhatikan kontradiksi terhadap klaim keimanan di hati sesama muslim. Selain itu panggilan ini juga untuk muqasy-qasyah (membongkar) makar terhadap

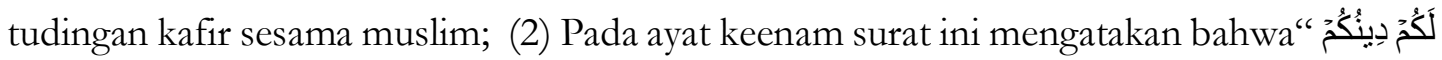
"وَلِيَ دِينِ / Untukmu agamamu, dan untukkulah, agamaku/ sebagai mitos yang menggambarkan konsep tolarensi dan moderasi beragama. bahwa sikap toleransi itu juga harus dibangun terhadap perbedaan dalam memahami khazanah keislaman antar sesama umat muslim. Selain itu, ayat ini juga memiliki makna konotasi bahwa dalam beragama sesama muslim memiliki sikap moderat terhadap perbedaan pemahaman dalam khazanah keislaman.

\section{DAFTAR PUSTAKA}

Abu, Bahrun Bakar, terj. Alfiyah syarh ibnu aqil. (2018). Bandung: Sinar Baru Algesindo Ad-Dausy, Muhyiddin. (1993). I'robul Qur'an Al-Karim Wa Bayanubu. Beirut: al-maktbah al-'ashriyah

Iyubenu, AH Edi. (2017). Islam yang Menyenangkan. Yogyakarta: IRCiSoD (Anggota Ikapi), 2017.

(2020). Berislam dengan Akal Sehat. Yogyakarta: Diva Press

Al-Bajuri, Ibrahim. (2012). Fath al-Rab al-Bariyah 'ala Dur al-Bariyah Nadzmi Jurmiyah. Jakarta: Darul Kutub Islamiyah

Barthes, Roland. (2017). Elemen-Elemen Semiologi, Terj. M. Ardiansyah, Yogyakarta: Basabasi

..........., Terj. Nurhadi, A. Sihabul Millah. (2018). Mitologi. Bantul: Kreasi Wacana .terj. Sterphanus Aswar Herwunarko. (2007). Petualangan Semiologi. Yogyakarta: Pustaka Pelajar

Busro, Muhtarom. (2015). Sorof Krapyak “Metode Krapyak". Yogakarta: Putra Menara Jogja

Cobley, Paul, dan Litza Janz. (2002). Mengenal Semiotika For Beginners. Bandung: Mizan Media Utama

Faizah, Chatirul. (2015). "Ajaran Moral dalam Kisah Nabi Yusuf A.S (Analisis Semiotika Roland Barthes)", Skripsi UIN Walisongo Semarang

Ghulayani, Mushtofa. (1993). Jami'u Durus, juz I, Bairut, juz II, cet ke-8, Beirut: alMaktbah al-'Ashriyah 
JALSAH: The Journal of al-Quran and as-Sunnah Studies

Faculty of Ushuludin IIQ An-Nur Yogyakarta

Vol. 1 No. 12021

https://jurnalannur.ac.id/index.php/jalsah

Halimatus, Yulia Zahroh. (2019). "Toleransi Antarumat Beragama (kajian tematik surat al-Kafirun dalam tafsīr Rībaṭ al-Quran karya Abuya Misbah Sadat)", Skripsi Universitas Islam Negeri Sunan Ampel

https://www.nu.or.id/post/read/103224/tentang-non-muslim-bukan-kafir, diakses pada 06/01/2020. Pukul 22.36 WIB.

Lustyantie, Ninuk. (2016). "Pendekatan Semiotika Model Roland Barthes Dalam Karya Sastra Prancis”, Jurnal Diskursus Islam, Vol. 4, No. 3, 2016

Millah, Shihabul. (2017). Semiotika Alquran Mubamad Arkoun, Yogyakarta:CV Lintang Hayuning Buwana

Muchtar, Adeng Ghazali. (2016). "Toleransi Beragama dan Kerukunan Dalam

Perspektif Islam”, Jurnal Agama dan Lintas Budaya, Vol. 01, No. 01, 2016

Qosim, Abi Zamaksyari. (2009). Tafsìr al-Kasyäf. Libanon: Daarul Marefah

Qur'an Kemenag, Qur'an In Word, Terjemahan Kemenag 2002. Add-in

Quthb, Sayid. Ttp. Tafsìr fi Ziläli al-Quran, Juz 29-30. Beirut: Dar al-Syuruq

Shihab, M. Quraish. (2005). Tafsir al-Misbah Pesan, Kesan, dan Keserasian al-Quran, Cet IV. Jakarta: Lentera Hati

(2015). Kaidah Tafsir Syarat, ketentuan, dan Aturan yang Patut Anda Ketabui Dalam Memahami Ayat-ayat al-Quran, Cet. III, Tangerang: Lentera Hati , (2018). Sirah Nabi Muhammad. Tangerang: Lentera Hati

Sunardi, St. (2013). Semiotika Negativa, Yogyakarta: Penerbit Buku Baik

Suryana, Toto. (2011). "Konsep dan Aktualisasi Kerukunan Antara Umat Beragama", Jurnal pendidikan Agama Islam-Ta’lim, Vol. 09, No. 02, 2011

Zajuli, Mohammad. (2014). Sejarah Agama-agama Manusia, Yogyakarta: PT Buku Seru 